\title{
THE ACADEMIC CAREER AND ACHIEVEMENTS OF YUANPENG HONG
}

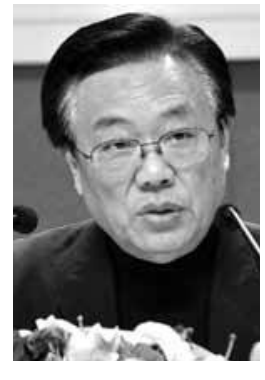

Bo Chen

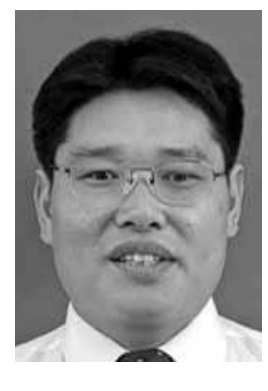

Bo Chen is an associate professor in the School of Economics at Shanghai University of Finance and Economics. His primary research is in the economic theory of socialism. Email: bochen74@mail.shufe. edu.cn

Research in economics is one of the most challenging fields in China. Opinions vary greatly in a field that includes a large number of talented people. A group of older economists have contributed greatly to the field, and to the construction of socialist economy. They share rich life experiences, solid theoretical foundations, comprehensive knowledge, and a strong sense of duty and responsibility for development and social progress.

Among them, the distinguished economist Yuanpeng Hong has been recognized and praised by both his peers and society for his practice in firmly grasping the development of the era, and his abundant achievements.

\section{Yuanpeng Hong's Resume}

Professor Yuanpeng Hong was born in Rugao, Jiangsu Province, in October 1935. $\mathrm{He}$ is currently a professor and doctoral supervisor in the Institute of Economy at Fudan University in Shanghai. He has served successively as the Director of the Department of Economy, the Dean of the Institute of Economy, Chairman of the Higher Degree Committee, and head of post-doctoral mobile research center for Theoretical Economics at Fudan. He is also a member of the National Social Science Fund Group, director of the editorial committee of World Economic Papers, 
vice-chairman of the Chinese Research Board of Das Kapital, Chairman of the Research Board of Das Kapital in Comprehensive Universities all over China, deputy head of the Shanghai Economic Association, and vice-chairman of the Shanghai Collective Economy Research Center-among other posts.

Yuanpeng Hong has been engaged in the teaching of and research into Das Kapital, price theory, the theory of socialist economy, comparative economic theory, theory and practice of economic interests, theory of cooperative economy, and other fields. In 1989, he won a National Special Award for Outstanding Teaching Achievements among Chinese Universities for taking part in the course "Teaching Reforms of Political Economy." Yuanpeng Hong has published almost 300 academic papers in journals such as Social Sciences in China. He is also a co-author or one of the editors of over 80 books, nearly 30 of which have won awards. In 1984, he was appointed a professor. In 1990, he was recognized as a national middle-aged expert with outstanding contributions. Since 1992 he has enjoyed a special allowance from the State Council. He was listed in the 1992-93 edition of Who's Who in the World by the International Biography Centre (Cambridge, England), and has been included in the 23rd edition of the Dictionary of International Biography.

In 2012, Yuanpeng Hong won the 11th Shanghai Academic Award for Philosophical and Social Scientific Achievements and was widely recognized for his research, teaching and promotion of Das Kapital. He has also been recognized for his systematic and integrated work in problems in benefits in a socialist market economy, and for advancing innovative ideas, thus significantly contributing to theories of socialist economy.

Yuanpeng Hong started to learn about Marxist political economy in the early 1950s. He has been learning, teaching and researching in this field for more than 50 years. He is a student of Marxist political economy, as well as a continuously creative teacher and researcher. It is no wonder that he has won such rich honors, because of his unique work and contributions in so many areas.

\section{Yuanpeng Hong's Achievements in Das Kapital Research}

Yuanpeng Hong worked in collaboration with Professor Zhang Xunhua in completing the Synopsis I, Synopsis II and the Trial Interpretation I of Das Kapital around 1977. These became the earliest interpretations of Das Kapital in China. All three books won the third prize for Outstanding Philosophical and Social Scientific Achievements among colleges and universities in Shanghai in 1984.

In 1981, he began to independently compile the three volumes of the Draft of Das Kapital, some 600,000 words altogether. This book was originally mimeographed by such institutions as Tongji University and Municipal Party School. In 1982 it was stereotyped by Jiangsu Party School and released internally, and then spread 
widely across China. Based on this, it was subsequently developed into the four volumes of the New Textbook on Das Kapital (hereafter abbreviated to Textbook).

Textbook made several unique contributions. It stands out for its general introduction to the four volumes of Das Kapital as well as its introductions and summaries of every part, and its overviews of each chapter. In addition, Textbook accurately reflects the original work, with a clear synopsis of the main concepts of Das Kapital. It quotes the key original sentences containing the main conclusions and pivotal expositions as much as possible. Furthermore, Textbook introduces the basic concepts in Das Kapital in each summary according to the sequence of appearances of these concepts, in order to help readers understand the causes and effects of basic concepts in Marxist political economy.

Textbook arranged notes on difficult sentences and allusions in relevant parts and chapters, in order to help readers understand challenging concepts in Das Kapital. Textbook also includes all important argumentations in Das Kapital on philosophy, scientific socialism, political science, law and history, etc., which can promote deep understanding of Marxist theory. Furthermore, Textbook points to several disputable problems in theory to stimulate thinking and lay a basis for research in these problems. Textbook also ties some principles in Das Kapital to real problems of modern capitalism, and presents some new interpretations. Textbook is also closely linked to the realities of building socialism with Chinese characteristics.

Textbook includes several brief comments on theories that are relevant for analysis of contemporary bourgeois economy, including value, wage, profit, currency, interest, and rent. Textbook also lists several questions to help readers review and mull over each section of Kapital.

Textbook has been welcomed by many readers and experts, in particular for the questions it identifies as deserving of further research and thought. It won the third prize for Outstanding Philosophical and Social Scientific Achievements in Shanghai for 1986-93, as well as the second prize for Good Textbooks among Common Universities and Colleges in Shanghai in 1995.

To commemorate the hundredth anniversary of Marx's death, in 1983 Yuanpeng Hong published a monograph titled Difficult Issues in Das Kapital. Some 400,000 words long, the book connects basic theories in Das Kapital with realities of contemporary capitalism and socialist economy, and points to some critical issues long in dispute both in China and internationally. The book also advances personal opinions and some of the author's unique ideas, including whether the developing stage of capitalism can be skipped; two use values with different meanings; two sorts of currency crises; standards for classifying social economic stages; classification of circulation costs; classification of social reproduction; rules for rapid growth of means of production; whether socialist economic factors can exist inside capitalist society and socialist rent, etc. 
This work was introduced at the Chinese Book Exhibition in Hong Kong in 1995, and won the award for outstanding philosophical social scientific works in Shanghai (1979-85), as well as first prize for outstanding works in philosophy and social science among 13 provinces and cities in North China.

These achievements, along with the 2002 book, Concise Course of Das Kapital (Fudan University Press), typify the two main features of Yuanpeng Hong's research into Das Kapital: First is its close connection with social reality, especially socialist economic reality. This stems from his working experience and theoretic studies of socialist economy. While he was conducting research in socialist economy, he felt that it was necessary to delve into Das Kapital and connect it with socialist economic reality, and he did this by teaching and doing research in Das Kapital. The second feature is Yuanpeng Hong's combination of deep research and popularization.

Throughout the process of building socialism in China, the priority in theory has been on radical reforms, cleaning out all non-Marxism of either "Left" or "Right," while holding firmly to Marxism. Yuanpeng Hong has made many contributions in this respect. He can be called a firm Marxist economist.

\section{Yuanpeng Hong's Exploration for the Construction of Economic Discipline}

Professor Hong has not only steadily adhered to Marxist economics, he has also been an innovative Marxist economist. He aims at theoretical innovations mainly in the following areas:

\section{Development and innovation in Marxist economics}

Professor Hong believes that political economy is a discipline in constant development, one which should conduct theoretical innovation and help establish a new political and economic system according to the characteristics of the times and historical tasks. On how to develop political economy, Professor Hong proposes the following. Firstly, political economy cannot leave out the "political." From the point of view of system theory, the socio-economic system is a large system which is formed by the interaction of subsystems, including politics, economics, social and cultural factors, productivity and so on. Only by simultaneously considering all factors, such as the political, cultural and institutional, on the running of the economic system can we develop a scientific explanation of economic phenomena and political movements. Secondly, as a scientific study of the socio-economic system, political economy must consider a country's reality with its own characteristics. Now we are talking about the development of political economy, that is, to establish political economy with Chinese characteristics. Thirdly, it should be made clear that the object of study of political economy is the relations of production, 
but it should have theoretical innovation according to the characteristics of the times and the new historical mission to establish a new political economy. Based on the above understanding, Professor Hong advocates that it should create a new system of political economy based on the characteristics of the times and the new historical mission, to replace the old system of political economy constituted by the capitalist part and the socialist part of the two major blocks. The new political and economic system will be composed of the following parts. The first part is the change and internal transformation of the economic system; the second is the production process; the third is the exchange process; the fourth is the process of allocation; the fifth is the process of consumption; and the sixth is the history of the development of political economy.

\section{Development and innovation in Marxist economic theory}

Professor Hong thinks that Marxism is an open and living system, which constantly draws from and is continuously enriched and developed by practice, and integrates all useful achievements of human civilization. Yuanpeng Hong points out the rules of developing Marxist economic theory, that is, to stick to, to clarify, and to develop it.

Firstly, Professor Hong believes Marxist economic theory must include three basic aspects:

(1) It must rest on the major laws of socialist economic practice as revealed in the Marxist classics. For example, the fundamental task of socialism is to develop productivity. Professor Hong published the article "On the Internal Sources of Productivity" in The Ideological Front, discussing internal sources of productivity in 1978, which indicates that labor, science and technology, and the forces of nature are the three internal sources of productivity. At that time, most theorists who studied the productive forces had long been focusing on the level of superficial factors of production.

This paper was subsequently incorporated in the book On ProductivityProceedings on Problems of the Productive Forces since the Establishment of the Country, which was edited by the Institute of Economics of the Chinese Academy of Social Sciences, and incorporated into the Fourth Series of Das Kapital Studies of Beijing Normal University.

(2) Professor Hong also insisted on the generally applicable law of human society as revealed by Marx. This includes the law of growth of labor productivity, agriculture as the foundation of economy, enterprise management as the objective requirement of large-scale joint work, reproduction in any society requiring certain material reserves.

(3) Professor Hong insists on the use of Marxist method. The laws of motion of capitalist economy, such as those revealed in Marx's Das Kapital, have a certain 
application in study of development of socialist economy, while abandoning their capitalist nature and purpose.

Secondly, Professor Hong thinks that we should clarify many incomplete or incorrect understandings of Marxist economic theory, or even misunderstanding or misleading interpretations. For example, in 1981, Professor Hong published the article "Can't Socialist Economic Factors Be Produced Within Capitalist Society?" in Fudan Journal (Social Sciences Edition), aiming at criticizing the viewpoint of many books on political economy that socialist economic factors couldn't develop within capitalist society. In this article, he held that there existed socialist economic factors within capitalist society. This article brought about hot debate. Professor Hong then published another article, "On Socialist Economic Factors in Capitalist Society." In this article, he held that the viewpoint that socialist economic factors could not be generated within the capitalist society only after the seizure of power by the proletariat and that they can only develop gradually was not a Marxist viewpoint. He also believed that there should and must be socialist economic factors in capitalist society. He also pointed out that the reality of contemporary capitalism showed that socialist economic factors had existed in capitalist development. For example, the cooperative economy is an "active sublation" of the capitalist system; state monopoly capitalism is the entrance to socialism; the stock economy is a transitional form from capitalism into a socialist economy; economic planning is the "surrender" of the unplanned production of the capitalist society to the forthcoming planned production of the socialist society; the socialization of the social welfare system is the partial adjustment of the capitalist relations of distribution; and so on. Professor Hong pointed out the fact that socialist economic factors existed in capitalist society strengthened the confidence in socialism, and helped correctly understand problems of contemporary capitalism and the future of proletarian revolution.

With respect to the problem of socialist accumulation, Professor Hong published the article "On Several Problems of Socialist Accumulation" in Economic Research in 1978. This article considers accumulation as the main source of expanding reproduction, but not the only one. His thesis immediately triggered a fierce controversy among theorists. Subsequently, he published additional articles arguing that accumulation is not the only source of expanding reproduction, and theoretically explaining and demonstrating his point. His 1980 article, published in Academic Monthly, and entitled "Accumulation Is Not the Only Source of Expanding Reproduction," was named the Outstanding Paper in Economic Science of 1979-83 by the Shanghai Economic Association.

In another example, in the past, a widespread misconception was that rent would be eliminated with the elimination of private ownership of land. But Professor Hong pointed out that as long as there was land ownership, there would be rent. 
The socialist revolution established public ownership of production and eliminated private ownership of land, but did not eliminate land ownership, so land rent would continue. Moreover, in order to end serious waste in use of land, and prevent huge profits by individuals and consequent loss of national income from real estate transactions, we must admit that land rent still exists after a socialist revolution.

Finally, it is especially noteworthy that Professor Hong believes that the development of Marxist economic theory has three aspects. First and foremost, it is important to combine the economic theory of Marxism with Chinese socialist realities to further develop the theory. Many theoretical conclusions of classical Marxist theorists should be updated with the development of practice after socialist revolution, such as the theory of single public ownership, the theory of highly centralized planning, and the theory of distribution of products according to labor. Second, we should learn from and draw from the reasonable elements of western economic theory. He advocates critical understanding of western economics. Finally, the precious legacy of Chinese economic thoughts should be inherited and developed.

In addition, Professor Hong has conducted numerous studies with significant achievements. For example, his book The Trajectory of Economic Theory has gained great prominence. The book categorizes and compares ancient and modern economic theories according to different topics and creates a new system of the history of economic theories.

\section{Exploration in synthetic economics}

Professor Hong set out to create a long-awaited integration of economics on the basis of long-term theoretical explorations. He considers that the main theme of the development of economic theory is comprehensive innovation. Economic theory has been forming for more than 200 years, evolving into a discipline, which has developed into a huge scientific system after lengthy internal evolution and integration. Everything in the world must be divided after being joined for a long time, and vice versa; then things that joined together are divided again, and vice versa; thus, joining and division interact with each other all along. Economic science shows an increasingly integrated trend of multi-level development based on evolution and intersection of many theories. Adam Smith's Wealth of Nations is an economics masterpiece formed by comprehensive innovation flowing from the various viewpoints of its ancestors. In the century after the publication of Wealth of Nations, along with the development of science and technology and their use in production, and with the refinement of the division of labor, the economic system became increasingly complex. Accordingly, economic science also experienced vertical and horizontal differentiation, which brought about many branches and schools of economics. The integration of economics also comes into being. 
Marx writes his immortal work, Das Kapital, through a comprehensive critique, absorption and synthesis of bourgeois economics. Marshall first creates modern microeconomics by compromising, reconciling or integrating preceding theory; Keynes sets the foundation of modern macroeconomics through comprehensive innovation in the theory and practice of macroeconomics. Samuelson rises to a higher level, taking on a variety of western economic theory, and forming an allencompassing system of integrated economics. Since then, with the rise of the new scientific and technological revolution, economics continues to divide and cross again on a new basis, which has now formed a more complex economics system of a classified subject.

The development of economic theory and practice of economic construction requires creating a synthetic socialist economics. Although all of the existing economic disciplines have provided certain answers from particular angles to various questions raised in the reform and development of the socialist economy, each wants to provide a clear and straightforward description to overall phenomena, yet the object of any existing economic subject cannot be inclusive.

The synthetic economics created by Professor Hong includes five aspects: the first is synthesis of productivity and the relations of production with the superstructure; the second is synthesis of macroeconomics, mesoeconomics and microeconomics; the third is synthesis of various socialist economic theories in different countries and of different branches and schools; the fourth is synthesis of different subjects of economic science and other related disciplines; the fifth is the synthesis of various economic methodologies.

A lot of fundamental research has been conducted and many achievements have been made by Professor Hong in synthetic economics. Professor Hong created the field, which is in a leading position in China. As early as 1985, he proposed establishing socialist synthetic economics in journals such as Fudan Journal (Social Sciences Edition), Review of Economic Research, and Social Sciences in China. His research was also in the lead among international economic theorists. According to reports, many economists in Germany, the United States, Australia and other countries are also striving to create the so-called mesoeconomics. Some have called it comprehensive economics, but the synthetic economics of Professor Hong has been more comprehensive, and includes foreign mesoeconomics to some extent.

\section{Yuanpeng Hong's Innovation in the Theories of Interest and Interest Relationship}

While studying the theory and application of economics for years, Yuanpeng Hong began to think about deeper problems in economics, then carried out research on the theory of interest and its application. This research is divided into two stages. 


\section{Stage 1: Systematic research in economic interest and economic interest relationships}

In a class for postgraduates majoring in economics, Yuanpeng Hong put forward a question, "What is the core of economics?" During the research and discussion with a group of doctors and young teachers, Yuanpeng Hong argued that the core of economics is economic interest, and economics is a science to study economic interests in the course of production, exchange, distribution and consumption. Based on this, he made three famous conclusions: "The core of all economics is economic interest," "The core of all economic activities is economic interest," "The core of all economic relationships is economic interest."

Yuanpeng Hong argues that among all social relationships, interest relationship is primary, and the essence of all economic relationships is the economic interest relationship.

Marxism has always attached great importance to economic interest and its relationships. Marx found that what people strive for is all interest-related, and the essence of all economic relationships is economic interest relationship. Das Kapital, the main work of Marxism, actually studies the relationship of capitalist economic interests, and explores the creation, exchange and distribution of this relationship in terms of production, circulation and distribution. Marxist economics serves the interests of the working class, or the majority. Lenin and Stalin also enriched the theory of Marxist economic interest relationship with their practice in the socialist construction of the former Soviet Union.

Guided by the theory of Marxist economic interest relationships, the Communist Party of China (CPC) has absorbed some useful parts of western economic interest theory, taking China's real condition into account, and greatly enriching and developing the theory of economic interest relationship. The CPC's Contribution to Marxist Economic Interest Theory, published by Yuanpeng Hong, won third prize for outstanding achievements in studying and propagating Deng Xiaoping Theory in Shanghai.

Yuanpeng Hong thinks that in the socialist market economy, the economic interests of participants are diversified, and various economic relationships are found anytime and anywhere. Seen from a holistic or microscopic perspective, there are economic interest relationships between the central and local governments, among the state, enterprises and individuals, between regions, between workers and peasants, between factors, between individuals, etc. Seen from the perspective of industry or sector, there are economic interest relationships in the agricultural sector, the industrial sector, the financial field, real estate, the leisure industry, and in the course of opening to the world, etc. Seen from the perspective of ownership or economic element, there are economic interest relationships of state-owned economies, cooperative economies, shareholding economies, private economies, 
sino-foreign cooperative economies, etc. Seen from the perspective of specific issues of research, there are economic interest relationships of economic growth, economic reform, inflation, RMB exchange rate, and the environment, etc.

Yuanpeng Hong also argues that in a socialist market economy, the economic interests of participants are diversified, the economic interest relationships are different and complex and conflicts in interest are unavoidable. But the relationships among interests can be reconciled. To do this, it is necessary to start with pursuing comprehensive economic interest based on the interest of all the participants, and build a mechanism to balance the economic interest in socialist market economy: interests of the individual should be subordinated to the interests of the collective; partial interests to overall interests; temporary interests to long-term interests; the interests of the majority should be protected, the excessive profits of the minority be limited; the legal interests should be safeguarded, and illegal interests should be fought against. Meanwhile, the economic interest, political interest and cultural interest should be combined so as to promote our material and spiritual civilization.

The research in economic interest relationships has great significance both in theory and practice. It gives us a new perspective to study Marxist economic theory, broadens the research of socialist economic theory, perfects and deepens the construction of economic subjects, and is thus of theoretical significance. The development, reform and stability of socialism can't ignore economic interest relationships, so the study of these relationships has great practical significance.

Yuanpeng Hong's research on the theory and application of economic interest has led to great achievements, summarized in the Series on Economic Interest Theory and Application, edited by Yuanpeng Hong and published by Fudan University Press. The series includes The General Theory of Economic Interest Relationships, The Theory of Comprehensive Economic Interest, The Theory of Public Interest, The Theory of Opportunity Interest, The Theory of Risk Interest, The Theory of Sharing Interest, The Theory of Innovative Interest, and The Theory of Security Interest. In addition to the series, The Theory of Common Interest, co-edited by Yuanpeng Hong and others, was published by Shanghai People's Press. The Theory of Trade Interest and The Theory of Peasants' Interest were also published. Two papers by Yuanpeng Hong, "The Ten Interest Relationships in Socialist Market Economy" and "The CCP's Contribution to Marxist Economic Theory," won a second prize and a third prize respectively for outstanding achievements in studying and propagating Deng Xiaoping Theory.

\section{Stage 2: Research on development and changes in interest relationships in China in the new era}

2005 was the first year that major grants sponsored by the National Social Science Fund were decided through open bids. Research in the Development and Change in 
Interest Relationships in China of a New Era, with Yuanpeng Hong as the principal investigator, received one of the first such grants.

In a preliminary study, Yuanpeng Hong advanced the following three arguments:

First, interest is at the center of all social activities. In the present world, social activities are filled with conflicts. People in different groups, communities, ranks, classes, nations and countries have different interest objectives and demands. People's motivation in undertaking economic, political and cultural activities all flow from pursuit of their interests. Without interest, people lose their incentive in undertaking social activities. A socialist society is no exception.

Second, interest relationships (in the broad sense) are at the core of all social relationships. The essence of human beings is actually a combination of all our social relationships. The interest of individuals and the interest of the society are the premises and conditions of each other. Development of society should aim at increasing the interest of every individual while increasing the interest of the majority. Individual interest must be based on the interests of the society, the nation, the state and humanity, in accordance with the general trend of historical development and the interest of the public. Only in this way, can individual interest get a solid and secure foundation. Therefore, interest relationship is the core of social relationships and we must pay due attention to it.

Third, the core of all social sciences is the interest relationship. Different social sciences or scholars have different, even opposed explanations for the same social problem, and draw different ideological conclusions and opinions. The root cause lies in that when studying, explaining and trying to solve problems, different social sciences and scholars, consciously or unconsciously, tend to take the stance of a certain interest group, stand for and support its interests, accept the ideology reflecting it, and adopt the values it satisfies. As a consequence, social sciences must differ from natural sciences. In other words, the core of all social sciences is the interest relationship.

In terms of new features revealed with the development of China's economic society and changes in social interest relationships, Yuanpeng Hong furthered his research, and advanced some valuable views, such as the following:

He expressed his opinions on ten aspects of social interest theory: (1) interest is a combination of the material and spiritual wealth that people need to meet their own needs; (2) interest is eternal, while interest relationships keep changing; (3) interest relationships are the core of all social relationships; (4) social interest is a combination of many interests; (5) "value" is a measurement quantifying social interests; (6) social interest evolves regularly; (7) the fundamental interest of people is the starting point and end point of all activities; (8) social interest relationships are the main problem of Chinese people's inner contradiction in the new era; (9) the coordination of interest relationship is the key to building a harmonious 
socialist society; (10) Marxists have always attached great importance to interest relationships.

Yuanpeng Hong defined ten concepts related to interest theory and its application: (1) the theory of comprehensive interest; (2) the theory of harmonious interest; (3) the theory of shared interest; (4) the theory of open interest; (5) the theory of opportunity interest; (6) the theory of risk interest; (7) the theory of trade interest; (8) the theory of guarantee interest; (9) the theory of leisure interest; (10) the theory of future interest.

He summarized ten features of social interest relationships in the new era: (1) the notion of interest has been accepted by the public; (2) the agents of interest are diversified; (3) the sources of interest are diversified; (4) the requirement for interest goes public; (5) the interest gap is expanded; (6) the interest relationship is complicated; (7) the interest demand is comprehensive; (8) interest relationship is the major issue of the inner contradiction among people; (9) coordination of the interest relationship is the key to building a harmonious socialist society; (10) research in interest theory and its application is at its early stage.

Yuanpeng Hong summed up ten social interest relationships in the new era of China: (1) the economic interest relationship between the central and local government; (2) the economic interest relationship among the state, enterprises and individuals; (3) the economic interest relationship between regions; (4) the economic interest relationship between workers and peasants; (5) the economic interest relationship between industries; (6) the economic interest relationship between enterprises; (7) the economic interest relationship between individuals; (8) the economic interest relationship between mental workers and physical laborers; (9) the economic interest relationship between different owners of means of production; (10) the economic interest relationship between China and the rest of the world.

He suggested ten ways to coordinate social interest relationships in China in the new era: (1) the way to increase interests; (2) the way to integrate interests; (3) the way to share interests; (4) the way to synthesize interests; (5) the way to guarantee interests; (6) the way to compensate interests; (7) the way to check and balance interests; (8) the way to ensure fundamental interests; (9) the way to ensure social equity and justice; (10) the way to coordinate interest in a timely manner.

Yuanpeng Hong pointed out ten issues that can be further explored in social interest relationship theory and its application: (1) the definition of interest needs further research and consideration; (2) social interest and its connotation needs further discussion; (3) quantification of social interest is a problem to be solved; (4) the understanding of fundamental interest needs to be studied; (5) interest compensation needs further discussion; (6) virtual interest is an important subject that has not been well studied; (7) how to understand the basic interest relationship in the new era can be further studied; (8) whether the fundamental law in the development of 
social interest relationship can be decomposed in multiple perspectives; (9) what is the relationship between social interest and construction of harmonious society; (10) how to analyze the relationship between social interest and social science.

The research accomplishments above by Yuanpeng Hong were not only thought highly of by the central government and relevant ministries, but also drew great attention in academia.

The series on interest relationships in the new era edited by Yuanpeng Hong include "Introduction of Interest Relationship - a Final Report of the Research on the Development and Change of Chinese Social Interest Relationship in New Era," "The Theory of Evolution of Social Interest Relationship," "The Theory of Holistic Interest," "The Theory of Local Interest," "A Comparative Study of Interest Theories," "Economic Globalization and the Change in our Interest Relationships," "Market Economy in the Light of Interest," "The Theory of Interest between Employer and Employee," "The Theory of Enterprise Interest," and many more papers.

"The Theory of Evolution of Social Interest Relationship," which developed from the project "Research on the Development and Change of Chinese Social Interest Relationship in New Era," was selected into Important Report (No. 56) of the National Social Science Fund, which is used as a source of reference by the central leadership. It won a first prize among outstanding achievements in philosophy and social science research in Shanghai in 2008, and a second prize of the 5th outstanding research achievement in universities on humanities and social sciences.

The academic paper, "The Feature and Cause of China's Present Economic Interest Relationship," was reprinted in Xinhua Digest, as well as in Copy Materials of People's University, the Social Science Journal Digest of Institutions of Higher Education, and other journals. The Change of System and the Evolution of Economic Interest Relationship won third prize in the 8th Shanghai Outstanding Works of Philosophy and Social Science, and was reprinted many times. The Ten Ways to Coordinate Chinese Social Interest Relationship in New Era $(1,2)$ was also reprinted in Copy Materials of People's University, Social Science Journal Digest of Institutions of Higher Education and other publications.

\section{Yuanpeng Hong's Theoretical Innovation for Chinese Reforms}

There were two contradictory opinions among national theoreticians about how to carry out reforms before the Third Plenary Session of the 14th Central Committee of the Communist Party of China in 1993. One opinion held that enterprise reform was the core of economic reform, thus it should go first; the other opinion supported price reform. Whereas Yuanpeng Hong thought that economic reform was a systemic project and we shouldn't emphasize a certain kind of reform too much and carry out 
this kind of reform alone, nor should we carry out several tasks at a time without focus. He proposed to make enterprise and price reforms the core, in collaboration with economic reforms such as planning, revenue, finance, circulation, wage and social insurance, etc. As for enterprise reform, Yuanpeng Hong had already proposed an "all-round, multi-level and different-stage" reforming strategy. "All-round" meant that we should carry out reforms and adjustments in several aspects, including property right relations, economic mechanism and distribution relations, etc.; "multi-level" meant not "rigid uniformity" but dividing enterprises into different types, and carrying out respective strategies based on property right relations, economic mechanisms, and distribution relations; "different-stage" meant dividing the process of gradually reforming and revitalizing large and medium enterprises into several stages.

As for price theory, Yuanpeng Hong has been undertaking relevant research into socialist pricing and price reform. He thinks we should be guided by Marxist price theory and draw on reasonable elements of western price theory while inheriting the excellent elements in ancient Chinese price ideology and drawing lessons of pricing from socialist countries. He published a series of papers on these questions and a book titled The Development of Price Theory and Formation of Socialist Prices, with many correct and penetrating views inside, for which he won seven prizes. In "Cost Problems in the Formation of Industrial Products," which was published in Social Sciences in China in 1984, he pointed out that the cost which forms price must be normal cost, social cost and planned cost. Then he expounded on the relationship between cost in price formation and the cost in economic accounting.

There were three main opinions both in China and internationally about what interest rate should be adopted in price formation: the return rate on capital, the return rate on wages, and the return rate on cost. Yuanpeng Hong put forward a fourth to adopt the return rate on processing cost in forming the price of industrial products, which could overcome the defect that the return rate of capital overemphasized the influence of past labor on price formation, could overcome the defect that the return rate of wage can't reflect the influence of the change of productivity on price formation, and could overcome the defect of double counting of profits in the setting prices according to the return rate of cost. This could bring prices closer to the value of products. Yuanpeng Hong, after years of research on price theory, put forward his own price reform theory: firstly, he pointed out a four-sequence theory on the formation of socialist prices, which were: underlying price as value theoretical price as transformed value target price as planned price, and market price as real price. Secondly, he pointed out that the target form of socialist price reform was market price.

The 14th session of the National People's Congress in 1992 had already set the goal of structural reform to lead to a socialist market economy. One of the main 
goals was to integrate enterprise reform, price reform and a series of other reforms, and to carry them out together. Yuanpeng Hong's theory was ahead of its time.

What is the fundamental principle guiding the market economy in the process of building a socialist market economy? Opinions vary in the theoretical field. Some think it should be the law of supply and demand, others the law of competition. Yuanpeng Hong has insisted that the fundamental guiding principle should be the law of value. Under the circumstances of market economy, the law of value adjusts various areas and aspects, including production, circulation, distribution and consumption in social economy. In production, it leads to transferring means of production and labor in every area of national economy according to the two meanings of socially necessary labor time, and adjusts enterprises' production and allocation of social resources; in circulation, it requires every producer and seller to carry out fair exchanges according to the principle of equal exchange; in distribution, the law of value regulates the distribution of products and surplus product; in consumption, it could regulate consumers' demands. He also points out, since the law of value is the fundamental discipline of socialist market economy, China must stick to it and do as it requires while carrying out socialist market economy. We need not only grope for stones to cross the river, we should also master the laws of crossing the river.

On the shareholding co-operative system, it is generally thought that this is a new form of organizing collective economy through profound reforms of collective ownership enterprises. Yuanpeng Hong says in one of his published articles, that this sort of shareholding co-operative system is narrowly defined. He thinks there is another sort of shareholding co-operative system. A shareholding co-operative system in a common sense is a kind of new co-operative economy growing by using the organizing form of contemporary shareholding economy. It draws lessons from the organizing and operating methods of the shareholding system, takes a new form of economic organization with means of production such as capital, labor, land, equipment and technology, etc. as investing shares. The shareholding co-operative system could be based on the original corporate enterprises with the state-owned economy as its focus and could draw on the principle of co-operative economy, thus forming the enterprise system combining share capital with co-operative labor; the shareholding co-operative system can also be a new enterprise formed by private enterprises after they take ownership of the shares and co-operate. However, no matter what kind of shareholding co-operative enterprise, it is no longer the original state-owned economy, collective economy or private economy. It will be a new form of shareholding co-operative system, a new form of socialist ownership and an important form of socialist ownership with state ownership dominant. And it will probably be the trend of socialist ownership. China's shareholding co-operative system is in the ascendant and is quite promising. 
In keeping with the deepening of structural reform of socialist market economy, Chinese economic elements and interests have become more and more diversified, and modes of distribution are gradually changing as well. The Communist Party and the central government have put forward a new income distribution system with work as the main source of income, and diversified methods of distribution as supplements. Therefore, reflections and disputes arose within the theoretical field on issues of labor value, exploitation and social class, etc.

Yuanpeng Hong points out ten rules for acknowledging labor and labor value. He thinks we should first carefully study Marxist economics and western economics in order to deepen our understanding of labor and labor value. Marx detailed analysis on how labor can create value. Some of his theories should be deepened and some should be further developed. We should be clear about the relations and differences between value creation, value formation, value realization and value distribution. We cannot roughly say that capitalists or capital could or could not create value, we must look at this question dialectically, divide it into two aspects to analyze. The labor theory of value is the fundamental discipline of market economy. We must accept surplus value if we accept the labor theory of value. Participating in the distribution of surplus value does not necessarily mean exploitation. There is still exploitation in China. We should start from the "Three Favorables," which means whether it is favorable to the development of the productivity of the socialistic society, whether it is favorable to the building-up of the comprehensive national strength of the socialist nations, and whether it is favorable to the improvement of the living standards of the people, and allow normal exploitation, limit super exploitation, and sanction ruthless exploitation. The labor theory of value of Marx must be developed and can be developed, but cannot be negated easily. Yuanpeng Hong's work forms a comprehensive summary of debate on the labor theory of value in recent years, and many scholars and relevant government departments have paid attention to his arguments.

\section{Yuanpeng Hong's Contribution to the Popularization of Economic Theories}

Ordinary people can master theory and play their historic role only when theory comes out of academic study rooms. Yuanpeng Hong has therefore not only conducted research in deep theoretical problems, he has also devoted himself to popularizing Marxist economic theories, explaining them in simple language. This is another of his achievements.

In 1981, Yuanpeng Hong compiled An Introduction to Political Economy, with a second edition published in 1982, consisting of almost 150,000 words. This book is closely connected with the reality of Chinese socialist economic construction. 
It introduces the main theories and basic principles of political economy in simple language. It also introduces the importance of learning political economy, in recognizing historical trends and guiding socialist modernization, and how to learn political economy, etc. While explaining the basic theories, Yuanpeng Hong advances his own opinions and unique understanding of the theory of political economy. For instance, he proposes that the relations of production should have four aspects rather than three; there are three factors of productivity rather than two; there is neither a law of absolute poverty nor a law of relative poverty, but a law of poverty of the proletariat under capitalism, etc.

This book is a unique introductory textbook of political economy, which combines theory with practice and is well structured with focused topics. It is easy to understand, with theoretical depth and academic value. It does not vulgarize but popularizes theory. It was welcomed by readers and reviewed in ten newspapers and journals. In July 1983 it won first prize in the first awards for National Popularized Political Theoretical Readings. And it was listed as one of the introductory books for young people's national reading activity, as well as the introductory book for the Revitalize Reading Activity in China in 1984.

For the one hundredth anniversary of the publication of the second volume of Das Kapital, which Friedrich Engels had reorganized, Yuanpeng Hong compiled The Popularized Das Kapital. This was a true reflection of the original work, with close connection to the reality of socialist economy. It made an important contribution in the popularization of Das Kapital in the following aspects. (1) The book was rearranged to follow the original Das Kapital. It kept the systemic sequence of the original parts, chapters and sections. (2) It fully reflected the future look of Das Kapital, integrating its logic and art. It included not only the theories in the first three volumes, but also Part Four's introduction. (3) In light of Das Kapital's comprehensive content and length, the book provided several necessary notes on some important or debatable problems, to help readers accurately understand and master them. (4) It was closely connected with the practice of socialist economy, with special sections on the "realistic significance" following each chapter, briefly stating the role of learning Das Kapital's relevant principles in guiding socialist construction. (5) The language in this book is vivid, simple and interesting, appealing to both educated and new readers. It won third prize for Outstanding Books on the 35th anniversary of the Liaoning People's Publishing House. In 2009, the Shanghai Science and Technology Literature Press republished Popularized Das Kapital, which faithfully introduced the basic theories and ideas in Das Kapital, by using simple language completely and accurately. It also made a further abstract of the ideological and theoretical essence of the original work. It was selected by the Propaganda Department of the Central Committee of the CPC 
and General Administration of Press and Publication for outstanding popularized theoretical readings.

It is not easy to popularize economic theory. Writing an article ought to be based on three levels: first, using profound and difficult language to express simple thoughts; second, using profound and difficult language to express difficult thoughts; third, using simple language to express profound thoughts. Yuanpeng Hong's work reached the third level in popularizing Das Kapital.

Translated by Shan Tong East China University of Political Science \& Law 